\title{
Effect of Ferronickel Slag Powder on Microhydration Heat, Flow, Compressive Strength, and Drying Shrinkage of Mortar
}

\author{
Bong-Suk Cho $\mathbb{D}^{1},{ }^{1}$ Young-Uk Kim, ${ }^{2}$ Do-Bin Kim, ${ }^{2}$ and Se-Jin Choi $\mathbb{D}^{2}$ \\ ${ }^{1}$ Environment \& Resources Research Group, Research Institute of Industrial Science \& Technology, Pohang 37673, \\ Republic of Korea \\ ${ }^{2}$ Department of Architectural Engineering, Wonkwang University, 460 Iksan-daero, Iksan 54538, Republic of Korea \\ Correspondence should be addressed to Se-Jin Choi; csj2378@wku.ac.kr
}

Received 26 February 2018; Revised 27 April 2018; Accepted 23 May 2018; Published 8 July 2018

Academic Editor: Farhad Aslani

Copyright (C) 2018 Bong-Suk Cho et al. This is an open access article distributed under the Creative Commons Attribution License, which permits unrestricted use, distribution, and reproduction in any medium, provided the original work is properly cited.

\begin{abstract}
This paper investigates the effect of ferronickel slag powder on microhydration heat, flow, compressive strength, and drying shrinkage of mortar. In South Korea, approximately two million tons of ferronickel slag, a by-product of the nickel industry, are produced every year. However, a considerable amount of this by-product is treated as waste and dumped in landfills. Ferronickel slag powder was used to replace Portland cement at a ratio of $15 \%$ by binder mass. In addition, the mortar test with other cementitious materials, including blast-furnace slag powder and fly ash, was conducted and compared with the sample containing ferronickel slag powder. According to this investigation, the microhydration heat of mortar and concrete can be reduced with the appropriate use of ferronickel slag powder. In addition, in order to achieve higher concrete compressive strengths, it is apparently advantageous to use the ferronickel slag powder and fly ash together rather than using ferronickel slag powder alone.
\end{abstract}

\section{Introduction}

Ferronickel slag is an industrial by-product obtained after nickel ore and bituminous coal are melted at high temperatures and thereafter separated from ferronickel. Generally, the ferronickel slag is used as a substitute material for foundry sand, abrasive, and serpentine [1]. In Korea, approximately two million tons of ferronickel slag are produced annually, and most of them are landfilled and buried. Accordingly, they pose as a serious environmental problem.

In the case of the blast-furnace slag, which is a by-product of the steel industry, several studies on its use as a substitute material for cementitious materials have been reported [2-5]. Moreover, some studies on the application of the ferronickel slag in concrete production have been reported [6-21].

Choi et al. [6] investigated the alkali-silica reactivity of cementitious materials using ferronickel slag fine aggregates produced under different cooling conditions. In this study, the rapidly (water) cooled ferronickel slag exhibited higher alkalisilica reactivity than its gradually (air) cooled counterpart. In addition, the partial replacement of ferronickel slag with sea sand and cements with fly ash or ground-granulated blastfurnace slag was found to be effective in reducing the alkali-silica reactivity of cementitious materials containing ferronickel slag as fine aggregates.

Saha et al. [7] investigated the use of ferronickel slag as a fine aggregate. It was found that a $50 \%$ replacement of natural sand with the ferronickel slag resulted in a wellgraded fine aggregate and maximized strength development. In addition, the ferronickel slag was found to be environmentally compatible because the amount of heavy metals leaching from it is far below the regulatory limits.

Saha et al. [8] studied the occurrence of expansion as a result of alkali-silica reaction with ferronickel slag fine aggregates in ordinary Portland cement (OPC) and blended cement mortars. In this investigation, an accelerated mortar bar test (AMBT) was performed to measure the expansion of the mortar containing ferronickel slag aggregates. According to the AMBT results, the ferronickel slag was found to be reactive in the Portland cement mortar.

However, in these previous studies, ferronickel slag was mainly used as a substitute material for concrete aggregates, 


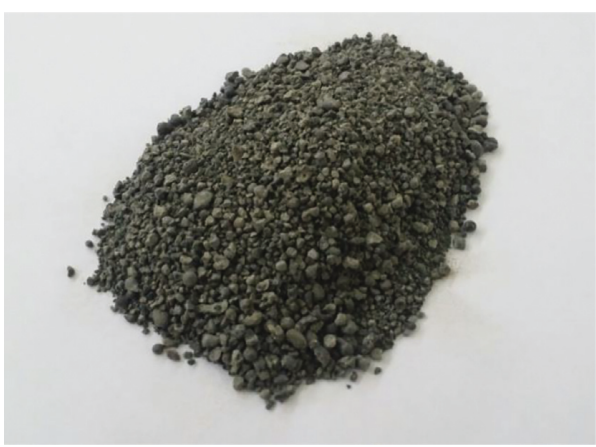

(a)

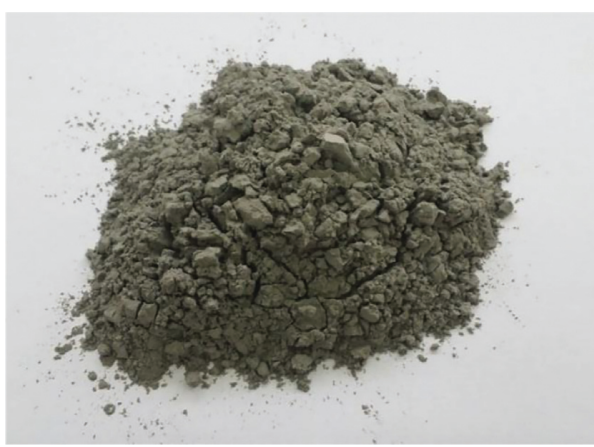

(b)

FIgURE 1: Ferronickel slag sample: (a) ferronickel slag aggregate; (b) ferronickel slag powder.

whereas there are only a few studies on its use as a supplementary material for cement.

In this study, the microhydration heat, flow, compressive strength, and drying shrinkage variation of mortar using ferronickel slag powder were investigated in order to utilize ferronickel slag as a substitute material for cement.

\section{Materials and Methods}

2.1. Materials. The cementitious materials used in this study were ASTM type I OPC, manufactured by the Asia Cement Co., Ltd. in Korea, and the blast-furnace slag powder, obtained from Daehan Slag Co., Ltd. in Korea. Moreover, fly ash products manufactured in the Honam thermoelectric power plant in Korea were acquired.

Ferronickel slag in the form of aggregates originating from POSCO in Korea was grounded to a powder level of $3500 \mathrm{~cm}^{2} / \mathrm{g}$ in a ball mill.

Figure 1 shows the ferronickel slag used in this study, and Figure 2 shows the SEM image of the ferronickel slag powder.

The aggregate used was natural sand with a maximum size of $5 \mathrm{~mm}$ and a fineness modulus of 2.73 .

Table 1 summarizes the chemical composition of cement, ferronickel slag powder, blast-furnace slag powder, and fly ash used in this study.

In this study, Series I and Series II experiments were conducted.

To investigate the characteristics of the mortar with various cementitious materials, in the case of Series I, the ferronickel slag powder, blast-furnace slag powder, and fly ash were used to replace $15 \%$ of the weight of the cement.

Additionally, a sample containing $7.5 \%$ ferronickel slag powder and $7.5 \%$ fly ash was prepared.

In the case of Series II, ternary mortar mixes were prepared by having two types of cementitious materials, including ferronickel slag powder, blast-furnace slag powder, and fly ash, replace $15 \%$ of the weight of cement to examine the characteristics of ternary mortar with industrial by-products.

A constant water-to-binder (W/B) ratio of 0.50 was used in this study.

The experimental plan is summarized in Table 2.

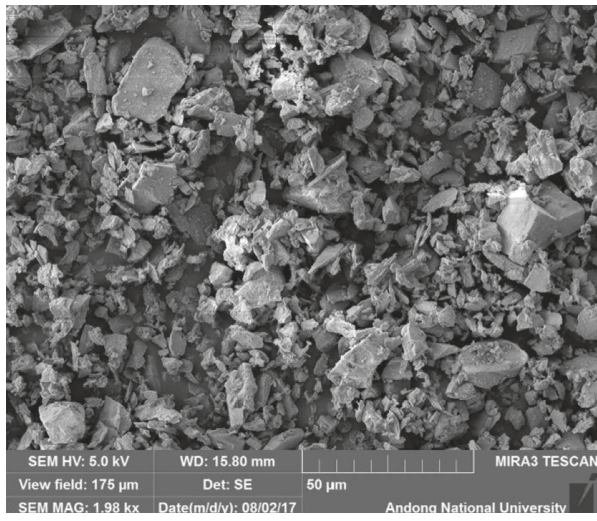

FIGURE 2: SEM image of ferronickel slag powder.

TABle 1: Chemical composition.

\begin{tabular}{lcccccc}
\hline & $\begin{array}{c}\mathrm{SiO}_{2} \\
(\%)\end{array}$ & $\begin{array}{c}\mathrm{Al}_{2} \mathrm{O}_{3} \\
(\%)\end{array}$ & $\begin{array}{c}\mathrm{Fe}_{2} \mathrm{O}_{3} \\
(\%)\end{array}$ & $\begin{array}{c}\mathrm{CaO} \\
(\%)\end{array}$ & $\begin{array}{c}\mathrm{MgO} \\
(\%)\end{array}$ & $\begin{array}{c}\mathrm{K}_{2} \mathrm{O} \\
(\%)\end{array}$ \\
\hline $\begin{array}{l}\text { Cement (C) } \\
\text { Ferronickel slag }\end{array}$ & 17.43 & 6.50 & 3.57 & 64.40 & 2.55 & 1.17 \\
$\begin{array}{l}\text { powder (FN) } \\
\begin{array}{l}\text { Blast-furnace slag } \\
\text { powder (BS) }\end{array}\end{array}$ & 48.91 & 2.08 & 11.6 & 0.82 & 32.41 & 0.09 \\
Fly ash (FA) & 64.61 & 13.98 & 0.32 & 40.71 & 6.43 & 0.60 \\
\hline
\end{tabular}

TABLE 2: Experimental plan.

\begin{tabular}{lccccccc}
\hline \multirow{2}{*}{ Test } & \multirow{2}{*}{ Mix } & \multirow{2}{*}{ W/B } & \multirow{2}{*}{ S/a } & \multicolumn{4}{c}{ Ratio (\%) } \\
& & & & C & FN & BS & FA \\
\hline \multirow{5}{*}{ Series I } & C100 & & & 100 & - & - & - \\
& FN15 & & & 85 & 15 & - & - \\
& BS15 & \multirow{2}{*}{0.50} & \multirow{2}{*}{0.49} & 85 & - & 15 & - \\
& FA15 & & & 85 & - & - & 15 \\
& F7.5 & & & 85 & 7.5 & - & 7.5 \\
\hline \multirow{5}{*}{ Series II } & C100 & & & 100 & - & - & - \\
& FN-BS & \multirow{2}{*}{0.50} & \multirow{2}{*}{0.49} & 70 & 15 & 15 & - \\
& FN-FA & & & 70 & 15 & - & 15 \\
& BS-FA & & & 70 & - & 15 & 15 \\
\hline
\end{tabular}

2.2. Mix Proportions and Specimen Preparation. The components of the samples were mixed in a mechanical mixer, and $50 \mathrm{~mm}$ cube molds were prepared for the compressive 


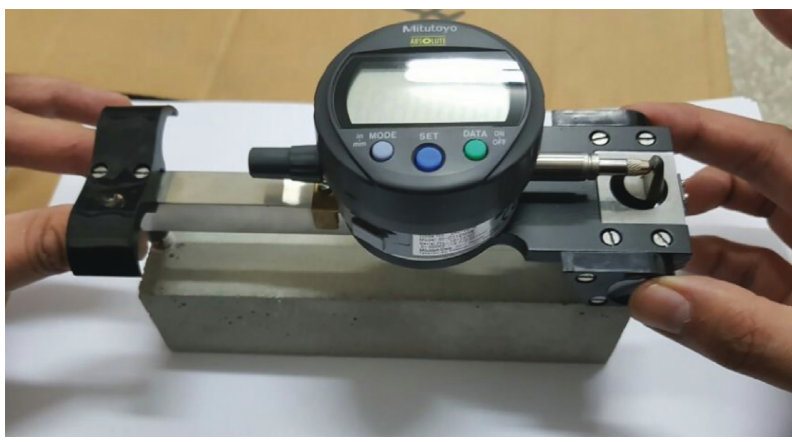

Figure 3: Strain gauge.

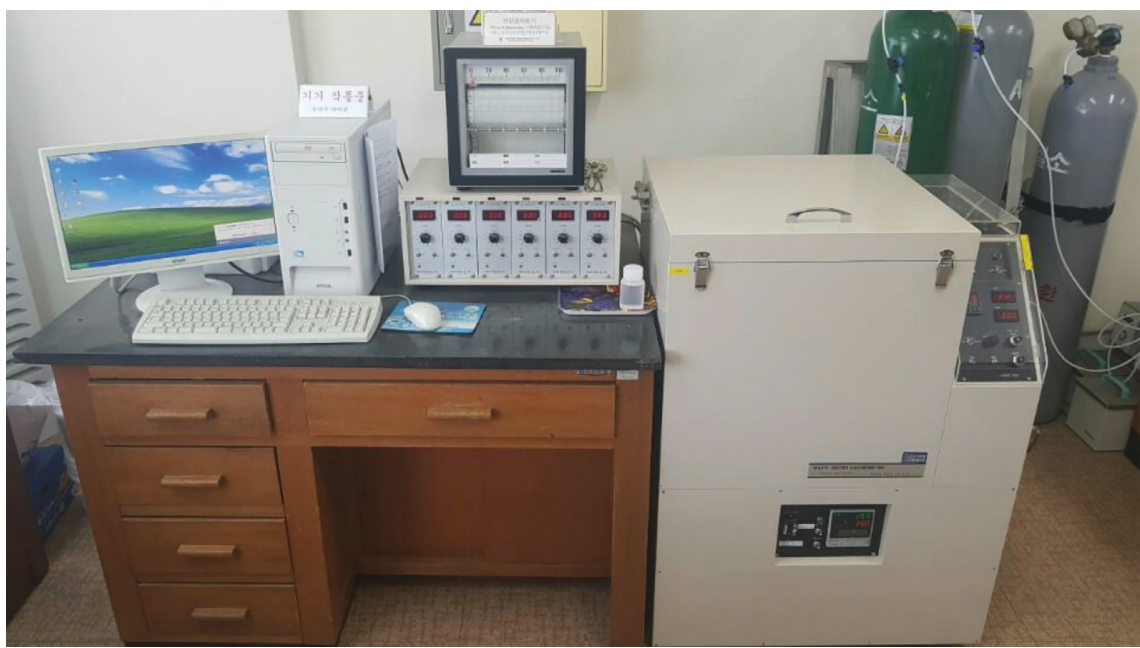

FIGURE 4: Multi-microcalorimeter.

strength test. Bar-type molds, $40 \times 40 \times 60 \mathrm{~mm}$, were made to measure the drying shrinkage.

After $24 \mathrm{~h}$, the compressive strength specimens were removed from their molds and cured at $20^{\circ} \mathrm{C}$ in a water tank.

The flow and compressive strength tests of each mix were conducted in conformance with KS L 5105 [15]. The strength test values were the average values of three samples.

The drying shrinkage test was conducted according to KS F 2424 [16] by using a mechanical strain gauge (Figure 3).

In order to measure the microhydration heat of the samples containing ferronickel slag powder, blast-furnace slag powder, and fly ash, cement was replaced by 10 and $20 \%$ of the ferronickel slag powder, $20 \%$ of the blast furnace slag powder, and $20 \%$ of the fly ash.

Figure 4 shows the microcalorimeter manufactured by Tokyo Riko Corporation, which was used for measuring the microhydration heat.

\section{Experimental Results and Discussion}

3.1. Heat of Microhydration. Figure 5 shows the variation in the microhydration heat of the specimens incorporated with cementitious materials.

As shown in the figure, a maximum microhydration heat of $66.29 \mathrm{cal} / \mathrm{g}$ was observed after $72 \mathrm{~h}$ in the case of the specimen that only uses cement. However, in other samples,

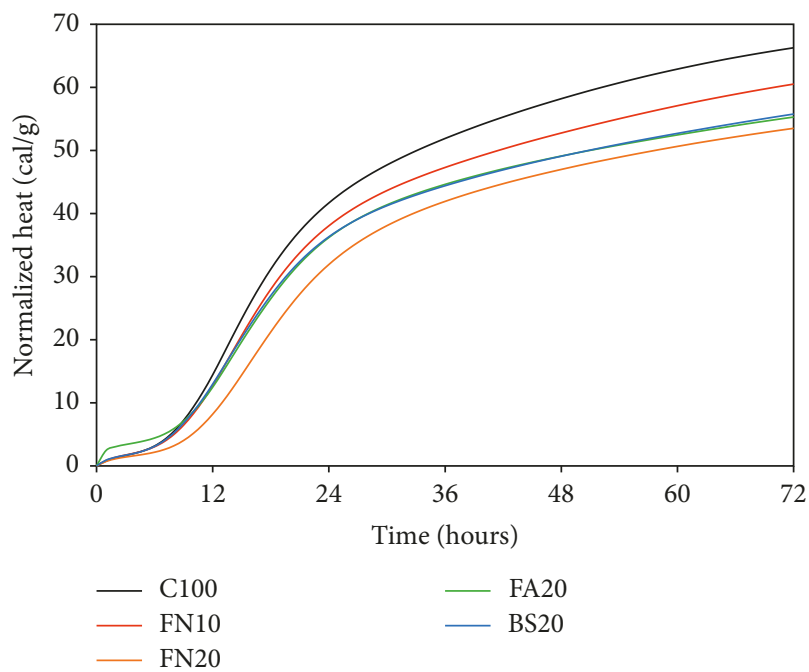

FIgURE 5: Heat of microhydration.

the microhydration heat decreased with the incorporation of ferronickel slag powder.

The samples FNS10 containing 10\% ferronickel slag powder and FNS20 containing 20\% of the same powder exhibited approximately 9 and 20\% lower microhydration heat, respectively, than the sample $\mathrm{C} 100$ containing cement alone. 


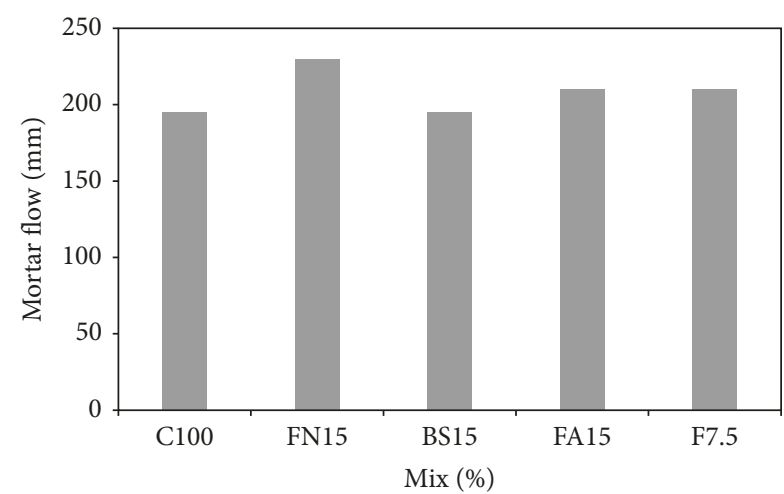

Figure 6: Mortar flow (Series I).

The test samples using the blast-furnace slag powder or fly ash displayed a similar reduction in microhydration heat in the range of $55.30-55.78 \mathrm{cal} / \mathrm{g}$ at $72 \mathrm{~h}$ of curing.

The sample FNS20 with $20 \%$ ferronickel slag powder exhibited low microhydration heat from the beginning of curing and presented approximately $4 \%$ less microhydration heat than the samples with the same amount of blast-furnace slag powder or fly ash.

Therefore, it is considered that the microhydration heat of the mortar and concrete can be reduced with the appropriate use of the ferronickel slag powder.

3.2. Flow. Figure 6 shows the flow of the mortar with cementitious materials.

As shown in this figure, the flow of the mortar with ferronickel slag powder is higher than that of other samples with the blast-furnace slag powder or fly ash.

This tendency is similar to previous results reported in the literature [17] that the fluidity of the mixture increases when the ferronickel slag is used as a component of the aggregates.

The flow of FA15 with 15\% fly ash and that of FNS/FA containing $7.5 \%$ ferronickel slag powder and $7.5 \%$ fly ash were similar.

Figure 7 shows the flow of ternary mortar mixes using two types of cementitious materials, including ferronickel slag powder, blast-furnace slag powder, and fly ash.

The flow of ternary mortar mixes was similar at values in the range of $150-165 \mathrm{~mm}$.

3.3. Compressive Strength. Figure 8 shows the variation of the compressive strength of the mortar with ferronickel slag powder, blast-furnace slag powder, and fly ash (Series I).

After $7 \mathrm{~d}$, the highest compressive strength (33.1 MPa) was observed in the C100 specimen, which contained cement only.

The compressive strengths of other specimens containing ferronickel slag powder, blast-furnace slag powder, and fly ash were in the range of 29-31 MPa. These showed $10 \%$ lower strengths than those of $\mathrm{C} 100$.

In the case of $28 \mathrm{~d}$ of curing, the highest compressive strength was obtained at approximately $39 \mathrm{MPa}$ in the C100

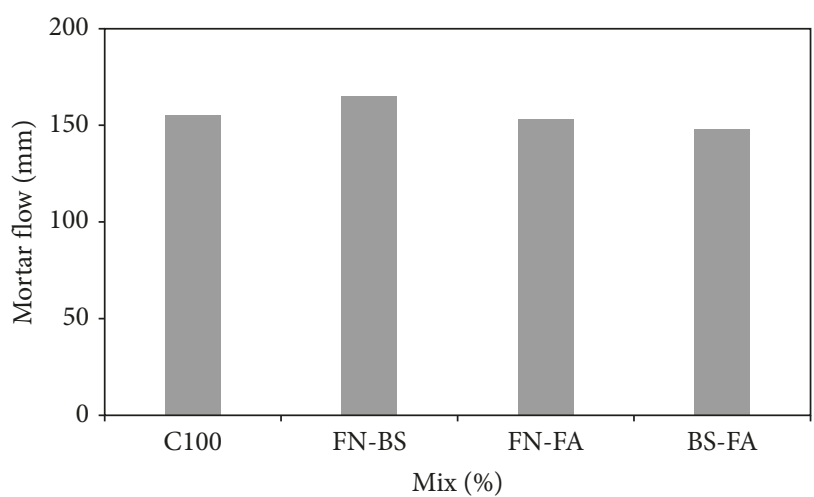

Figure 7: Mortar flow (Series II).

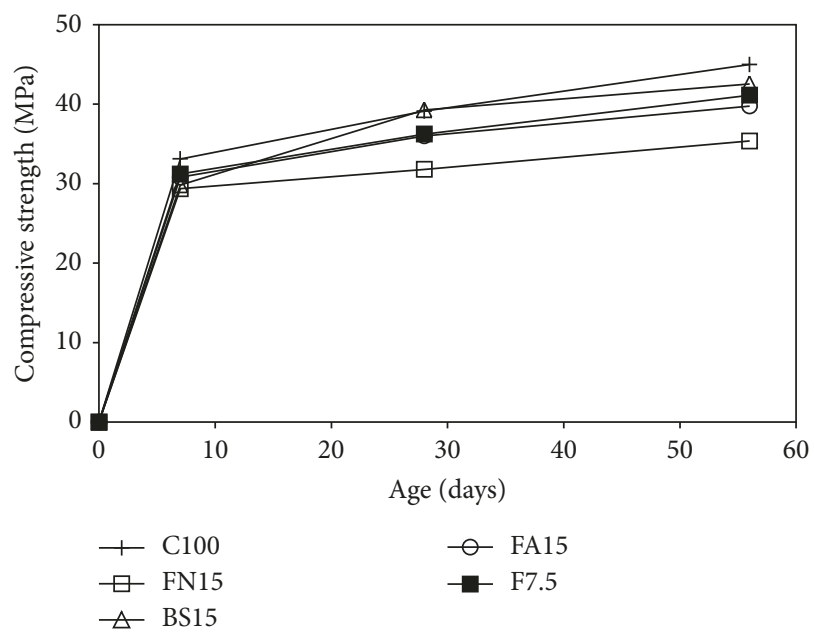

FIGURE 8: Compressive strength of the mortar (Series I).

specimen, which contained cement only, and the BFS15 specimen containing $15 \%$ blast-furnace slag powder.

The compressive strength of the FN15 specimen with $15 \%$ ferronickel slag powder was approximately $20 \%$ lower than that of the $\mathrm{C} 100$ specimen.

Note that the F7.5 specimen containing 7.5\% ferronickel slag powder and $7.5 \%$ fly ash exhibited approximately $13 \%$ higher compressive strength than the FN15 specimen.

Therefore, in order to achieve higher compressive strengths, it is apparently advantageous to use the ferronickel slag powder and fly ash together instead of using ferronickel slag powder alone.

The compressive strength of FA15 with 15\% fly ash was approximately $8 \%$ lower than that of $\mathrm{C} 100$.

After $56 \mathrm{~d}$, the compressive strength of the F7.5 specimen with $7.5 \%$ ferronickel slag powder and $7.5 \%$ fly ash was approximately $41 \mathrm{MPa}$, which was higher than that of the FA15 specimen with $15 \%$ fly ash.

Figure 9 shows the compressive strength of the ternary mortar using two types of cementitious materials, including ferronickel slag powder, blast-furnace slag powder, and fly ash (Series II).

After $7 \mathrm{~d}$, at $32.06 \mathrm{MPa}$, the compressive strength of the C100 specimen with $100 \%$ cement was higher than that of other mixes. 


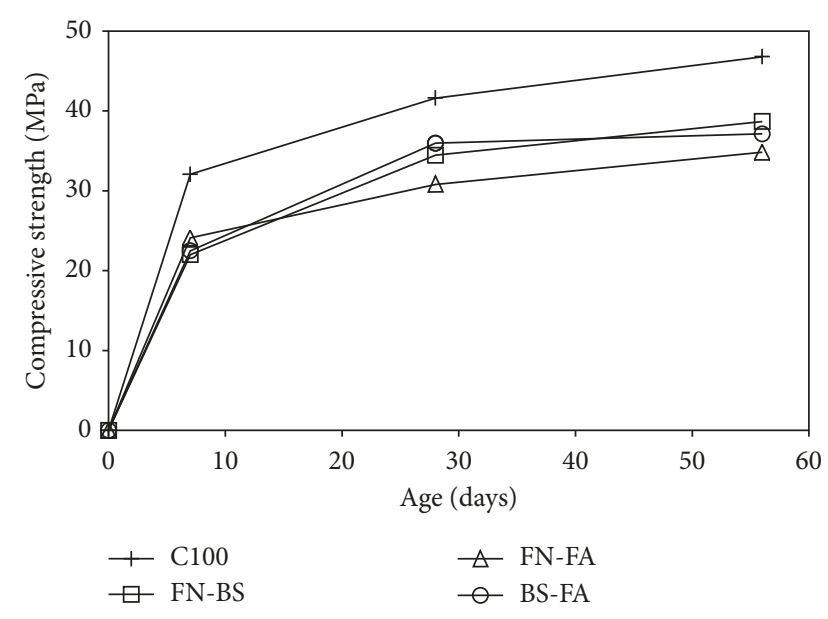

Figure 9: Compressive strength of the ternary mortar (Series II).

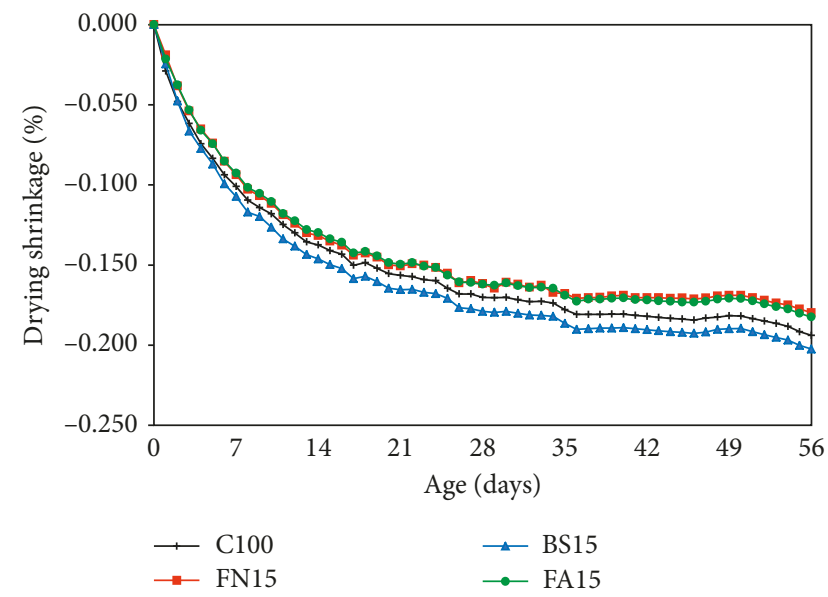

FIgURE 10: Drying shrinkage of the mortar (Series I).

The compressive strengths of FN-BS, FN-FA, and BS-FA specimens with two types of cementitious materials were in the range of 22-24 MPa, which were approximately $25-30 \%$ lower than those of the C100 specimen.

After $28 \mathrm{~d}$ of curing, the compressive strength of the C100 specimen with $100 \%$ cement was approximately $41.6 \mathrm{MPa}$.

The compressive strengths of FN-BS and BS-FA specimens containing ferronickel slag powder, blast-furnace slag powder, and fly ash were similar in the range of 34-35 MPa.

The compressive strength of the FN-FA specimen containing ferronickel slag powder and fly ash was the lowest at $30 \mathrm{MPa}$ after $28 \mathrm{~d}$.

In the case of $56 \mathrm{~d}$ of curing, the compressive strength of all mixes increased continuously.

3.4. Drying Shrinkage. Figure 10 shows the drying shrinkage of the mortar containing ferronickel slag powder, blastfurnace slag powder, and fly ash (Series I).

The drying shrinkage of C100 and BS15 specimens was approximately 0.222 and $0.231 \%$ after $56 \mathrm{~d}$, respectively. The drying shrinkage of BS15 with $15 \%$ blast-furnace slag powder was higher than that of other mixes.

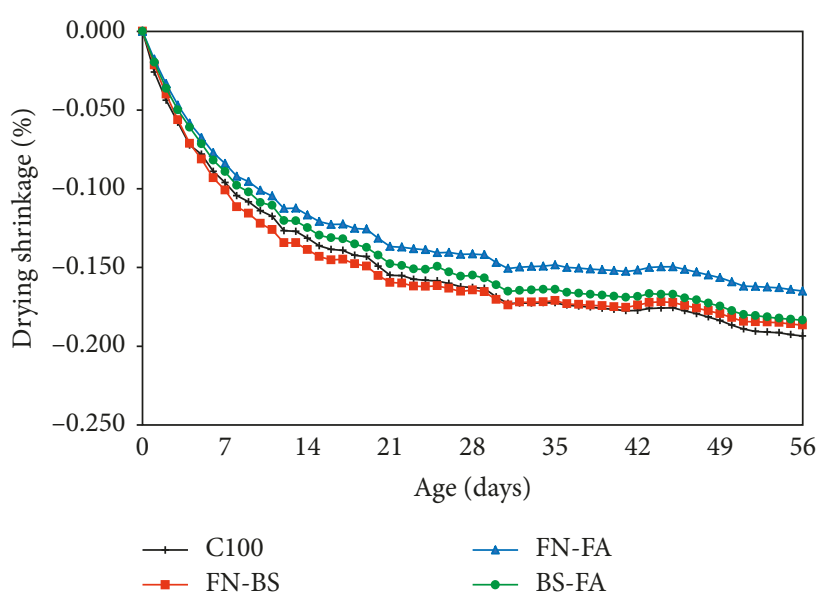

FIGURE 11: Drying shrinkage of the ternary mortar (Series II).

The drying shrinkage of the FN15 specimen with $15 \%$ ferronickel slag powder had the lowest value, which was approximately $8 \%$ lower than that of the C100 specimen.

It is considered that the use of ferronickel slag powder in the mortar or concrete can be effective in reducing drying shrinkage.

Figure 11 shows the drying shrinkage of the ternary mortar using two types of cementitious materials, including ferronickel slag powder, blast-furnace slag powder, and fly ash (Series II).

The drying shrinkage of FN-BS and BS-FA specimens was similar in the range of $0.184-0.187 \%$ after $56 \mathrm{~d}$. Moreover, the drying shrinkage of the C100 specimen containing only cement was higher than that of other mixes.

The FN-BS specimen containing the ferronickel slag powder and blast-furnace slag powder exhibited higher drying shrinkage than the $\mathrm{C} 100$ specimen in the early age. However, after $35 \mathrm{~d}$, the drying shrinkage of the FN-BS specimen was lower than that of the C100 specimen.

The drying shrinkage of the FN-FA specimen with ferronickel slag powder and fly ash had the lowest value of $0.165 \%$ at $56 \mathrm{~d}$. This value was approximately $15 \%$ lower than that of the $\mathrm{C} 100$ specimen.

\section{Conclusions}

The following conclusions were obtained from the present investigation:

(1) The maximum microhydration heat of $66.29 \mathrm{cal} / \mathrm{g}$ was observed after $72 \mathrm{~h}$ in the case of the specimen with cement only. However, as the ferronickel slag powder was incorporated into various samples, the observed microhydration heat decreased.

(2) The samples FNS10 containing $10 \%$ ferronickel slag powder and FNS20 with $20 \%$ of the same powder exhibited approximately 9 and 20\% lower microhydration heat, respectively, than C100 with 100\% cement. 
Therefore, it is concluded that the microhydration heat of the mortar and concrete can be reduced with the appropriate use of the ferronickel slag powder.

(3) The flow of the mortar with ferronickel slag powder was higher than that of samples with blast-furnace slag power or fly ash.

In addition, the flow of ternary mortar mixes with two types of cementitious materials including ferronickel slag powder, blast-furnace slag powder, and fly ash had approximately similar values in the range of $150-165 \mathrm{~mm}$.

(4) The highest compressive strength after $7 \mathrm{~d}$ of curing was observed in the $\mathrm{C} 100$ specimen containing cement only. Moreover, the compressive strengths of other specimens containing ferronickel slag powder, blast-furnace slag powder, and fly ash were approximately $10 \%$ lower than those of the C100 specimen.

(5) The compressive strength of the FN15 specimen with $15 \%$ ferronickel slag powder was approximately $20 \%$ lower than that of the C100 specimen after $28 \mathrm{~d}$.

Note that the F7.5 specimen containing 7.5\% ferronickel slag powder and $7.5 \%$ of fly ash showed approximately $13 \%$ higher compressive strength than the FN15 specimen.

Therefore, in order to achieve higher compressive strengths, it is apparently advantageous to use the ferronickel slag powder and fly ash together rather than using ferronickel slag powder alone.

(6) The compressive strengths of FN-BS, FN-FA, and BS-FA specimens with two types of cementitious materials were $22-24 \mathrm{MPa}$, which were approximately $25-30 \%$ lower than those of C100.

(7) The drying shrinkage of C100 and BS15 specimens was approximately 0.222 and $0.231 \%$ after $56 \mathrm{~d}$, respectively. The drying shrinkage of BS15 with 15\% blast-furnace slag powder was higher than that of other mixes.

The drying shrinkage of the FN15 specimen with $15 \%$ ferronickel slag powder had the lowest value, which was approximately $8 \%$ lower than that of the C100 specimen.

(8) The FN-BS specimen containing ferronickel slag powder and blast-furnace slag powder exhibited higher drying shrinkage than the C100 specimen during the early curing age. However, the drying shrinkage of the FN-BS specimen was lower than that of the C100 specimen after $35 \mathrm{~d}$.

(9) The drying shrinkage of the FN-FA specimen with ferronickel slag powder and fly ash had the lowest value of $0.165 \%$ at $56 \mathrm{~d}$. This value was approximately $15 \%$ lower than that of the C100 specimen.

In addition, further studies are needed to establish the mechanism and respective relationships between the microhydration heat, strength, drying shrinkage properties of the mortar containing ferronickel slag powder, and replacement ratio of ferronickel slag powder.

\section{Data Availability}

The data used to support the findings of this study are available from the corresponding author upon request.

\section{Conflicts of Interest}

The authors declare that they have no conflicts of interest.

\section{Acknowledgments}

This research was supported by the Basic Science Research Program through the National Research Foundation of Korea (NRF) funded by the Ministry of Science and ICT (NRF-2017R1A2B4004053).

\section{References}

[1] C.-H. Lee, "The status of construction recycling resources on global ferronickel slag market," Magazine of Korea Recycled Constriction Resources Institute, vol. 12, no. 3, pp. 54-58, 2017.

[2] Q. L. Li, M. Z. Chen, F. Liu, S. P. Wu, and Y. Sang, "Effect of superfine blast furnace slag powder on properties of cementbased materials," Materials Research Innovations, vol. 19, pp. S1-168-S1-171, 2015.

[3] A. Bouaziz, R. Hamzaoui, S. Guessasma, R. Lakhal, D. Achoura, and N. Leklou, "Efficiency of high energy over conventional milling of granulated blast furnace slag powder to improve mechanical performance of slag cement paste," Powder Technology, vol. 308, pp. 37-46, 2016.

[4] H. Yazıcı, M. Y. Yardımc1, H. Yigiter, S. Aydın, and S. Turkel, "Mechanical properties of reactive powder concrete containing high volumes of ground granulated blast furnace slag," Cement \& Concrete Composites, vol. 32, pp. 639-648, 2010.

[5] H. Yazıc1, H. Yigiter, A. S. Karabulut, and B. Baradan, "Utilization of fly ash and ground granulated blast furnace slag as an alternative silica source in reactive powder concrete," Fuel, vol. 87, pp. 2401-2407, 2008.

[6] Y. C. Choi and S. C. Choi, "Alkali-silica reactivity of cementitious materials using ferro-nickel slag fine aggregates produced in different cooling conditions," Construction and Building Materials, vol. 99, pp. 279-287, 2015.

[7] A. K. Saha and P. K. Sarker, "Sustainable use of ferronickel slag fine aggregate and fly ash in structural concrete: mechanical properties and leaching study," Journal of Cleaner Production, vol. 162, pp. 438-448, 2017.

[8] A. K. Saha and P. K. Sarker, "Expansion due to alkali-silica reaction of ferronickel slag fine aggregate in OPC and blended cement mortars," Construction and Building Materials, vol. 123, pp. 135-142, 2016.

[9] Y. W. Choi, M. S. Park, S. H. Bae, H. H. Lee, and B. S. Jo, "Properties of water granulated ferro-nickel slag as fine aggregate for concrete," in Proceedings of Korean Society of Civil Engineers, pp. 1462-1465, Incheon, Korea, 2010.

[10] M. S. Park, The Study on Quality Properties of Concrete Using Water Granulated Ferro-Nickel Slag for Fine Aggregate, Major in Civil Engineering, Semyung University Graduate School, Semyung, Republic of Korea, 2011. 
[11] P. S. Kim, The Study on Performance Evaluation of EcoFriendly Concrete Using Ferro-Nickel Slag for Fine Aggregate, Department of Civil Engineering, The Graduate School Hanyang University, Hanyang, Republic of Korea, 2013.

[12] H. S. Kim, Characteristics of Eco-Friendly Concrete for Precast Using Ferronickel Slag Fine Aggregates, Department of Civil, Architectural and Environmental System Engineering Sungkyunkwan University, Seoul, Republic of Korea, 2015.

[13] J. I. Park, S. H. Bae, Y. W. Choi, K. M. Lee, and B. S. Cho, "Mechanical properties and durability of concrete using ferronickel air cooled slag aggregate," in Proceedings of Korea Concrete Institute, pp. 471-472, Jeju, Korea, 2011.

[14] Y. W. Choi, M. S. Park, S. R. Oh, G. M. Lee, J. S. Kim, and B. S. Cho, "Evaluation of field applicability of concrete using water granulated ferro-nickel slag for fine aggregate," in Proceedings of Korea Concrete Institute, pp. 217-218, Korea, 2010.

[15] Korea Standards Association, "Testing method for compressive strength of hydraulic cement mortar," Tech. Rep. KS L 5105, Korea Standards Association, Seoul, Republic of Korea, 2007.

[16] Korea Standards Association, "Standard test method for length change of mortar and concrete," Tech. Rep. KS F 2424, Korea Standards Association, Seoul, Republic of Korea, 2015.

[17] Y. W. Choi, M. S. Park, K. M. Lee, S. H. Bae, and J. S. Kim, "Evaluation of optimum mixing rate and durability of concrete using water granulated slag fine aggregate," Journal of Korean Recycled Construction Resources Institute, vol. 13, pp. 120-127, 2011.

[18] B. K. Cho, H. H. Lee, Y. W. Choi, D. C. Park, and Y. C. Choi, "A study on performance of concrete using FeNi slag aggregate," in Proceedings of Korea Concrete Institute, pp. 583-584, Boryeong, Korea, 2014.

[19] W. J. Kim, S. B. Hong, P. S. Kim, and B. S. Cho, "Research on the concrete using ferro-nickel slag for fine aggregate," in Proceedings of Korea Concrete Institute, pp. 453-454, Pyeongchang, Korea, 2011.

[20] J. I. Park, S. H. Bae, J. W. Yu, Y. W. Choi, and K. M. Lee, "Characteristics of concrete using ferronickel air cooled slag aggregate," in Proceedings of Korea Concrete Institute, pp. 215-216, Gangchon, Korea, 2010.

[21] H. S. Kim, S. W. Choi, K. M. Lee, and S. J. Choi, "Compressive strength properties of steam-cured concrete using ferronickel slag fine aggregate," in Proceedings of Korea Concrete Institute, pp. 541-542, Gwangju, Korea, 2015. 


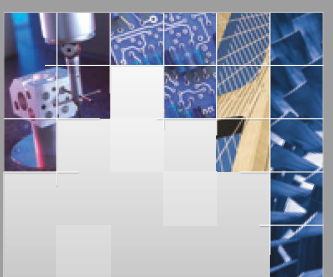

\section{Enfincering}
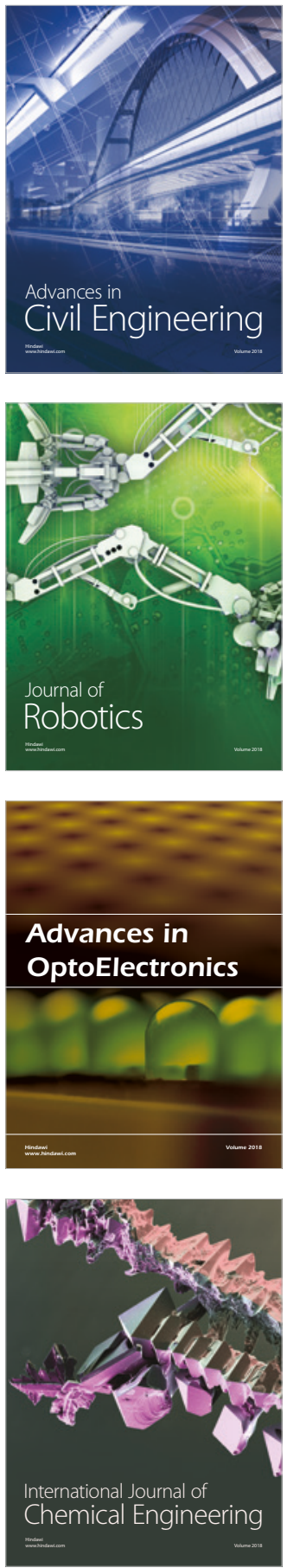

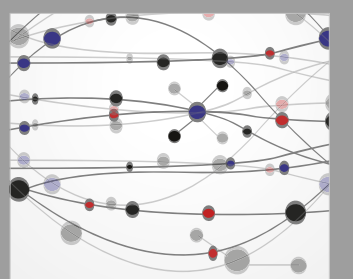

\section{Rotating \\ Machinery}

The Scientific World Journal

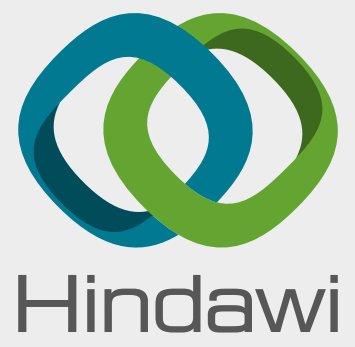

Submit your manuscripts at

www.hindawi.com
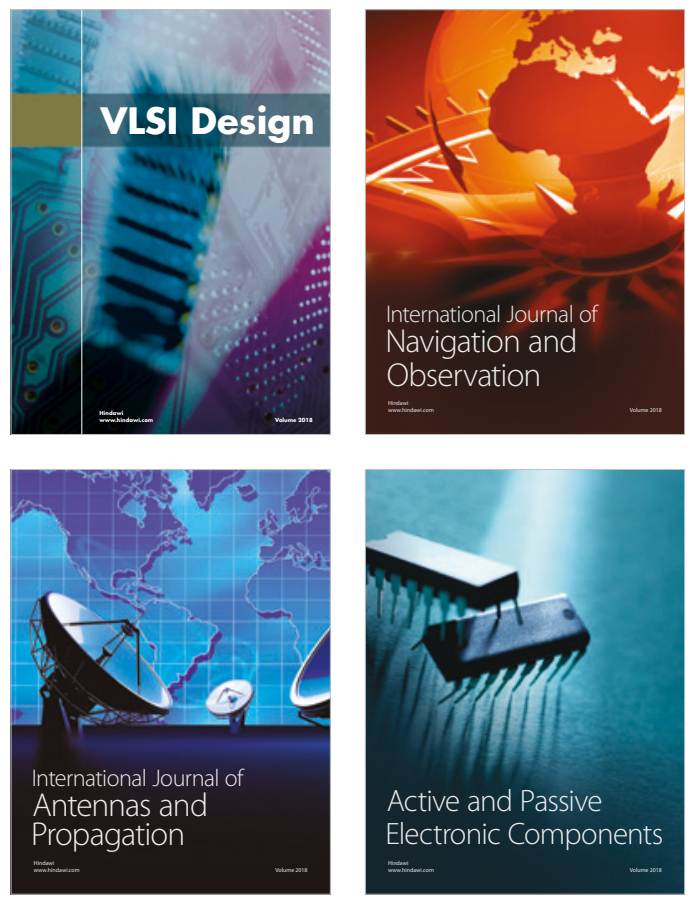
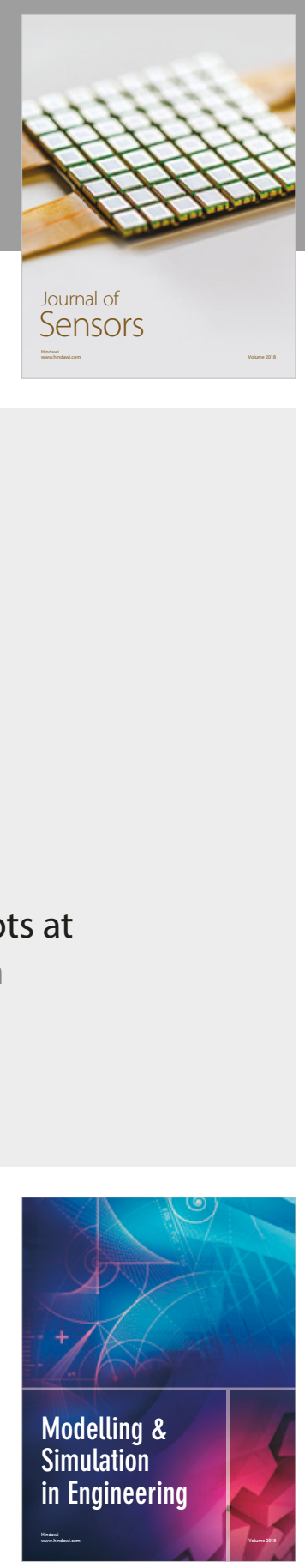

\section{Advances \\ Multimedia}
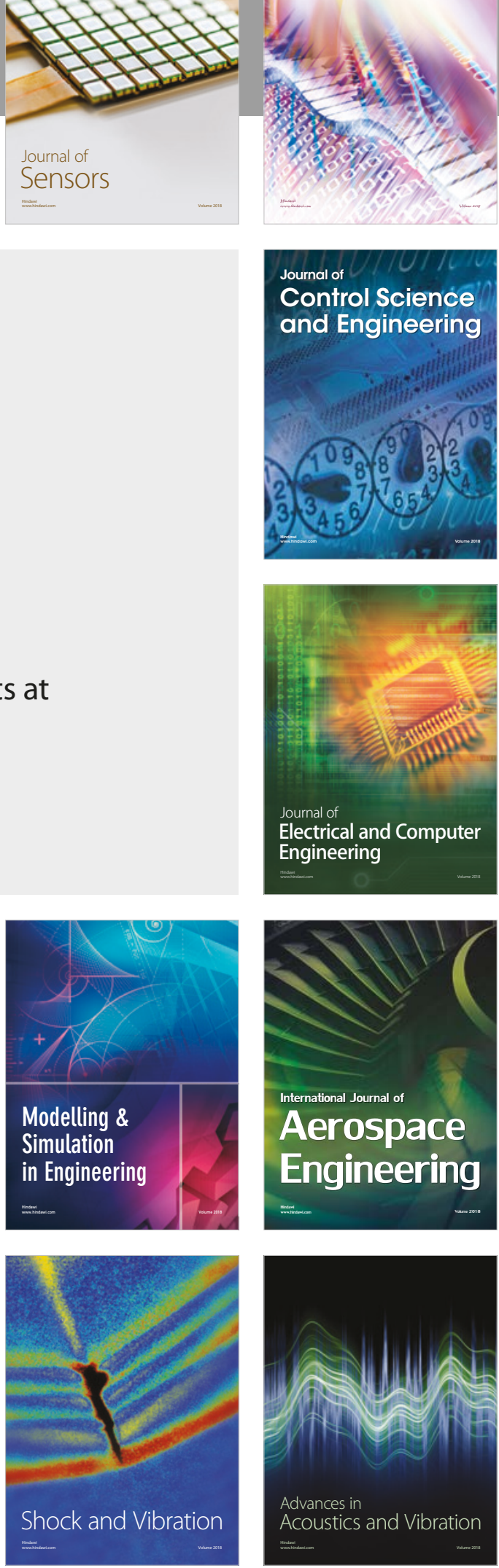